\title{
Seroprevalence of Brucella melitensis among Small Ruminants and Humans in Anand Region of Central Gujarat, India
}

\author{
R.R. Padher*, J.B. Nayak, M.N. Brahmbhatt, S.M. Patel and J.H. Chaudhary \\ Department of Veterinary Public Health, College of Veterinary Science and Animal \\ Husbandry, Anand Agricultural University, Anand, 388001, Gujarat, India \\ *Corresponding author
}

\section{A B S T R A C T}

\begin{tabular}{|c|}
\hline Keywords \\
\hline $\begin{array}{l}\text { Brucellosis, } \\
\text { Brucella } \\
\text { melitensis, } \\
\text { Small } \\
\text { ruminants, } \\
\text { Humans }\end{array}$ \\
\hline Article Info \\
\hline $\begin{array}{l}\text { Accepted: } \\
28 \text { February } 2018 \\
\text { Available Online: } \\
10 \text { March } 2018\end{array}$ \\
\hline
\end{tabular}

\section{Keywords} melitensis Small ruminants, Humans

\section{Accepted:} Available Online 10 March 2018

\begin{abstract}
Brucellosis is a zoonosis known to be a major public health hazard of great economic importance globally. The present study was taken up to ascertain the seroprevalence of brucellosis in goats, sheep, and humans of Anand, districts of the Central Gujarat region. Indirect enzyme linked immunosorbent assay (I-ELISA) were employed for detecting the brucella and Brucella melitensis antibodies from animals and humans. They were also compared in terms of their sensitivity and specificity. A total 325 sera samples including 100 from goats, 100 from sheep, and 125 from human beings collected from the Anand district. Out of 325 sera samples tested, overall seroprevalence was $93(46.50 \%)$ while species wise incidence was found to be $55(55.00 \%)$ and $38(38.00 \%)$ among goats and sheep, respectively. Out of $93(46.50 \%)$ seropositive samples $65(32.50 \%)$ were positive for Brucella melitensis comprising 46 goats and 19 sheep sera samples by I-ELISA. Seroprevalence of Brucella melitensis among sheep was $19.00 \%$ while among goat was $46.00 \%$ by I- ELISA. In case of sex wise seroprevalence of Brucella melitensis in male was $17.00 \%$ while in female was $48.00 \%$ by I-ELISA, respectively in small ruminants. In goats, sex wise seroprevalence of Brucella melitensis in male was $24.00 \%$ while in female $68.00 \%$ by I- ELISA. In sheep, sex wise seroprevalence of Brucella melitensis in male was $10.00 \%$ while $28.00 \%$ by I- ELISA in female. In humans, taluka wise seroprevalence of brucellosis was $12.50,33.33,16.66,14.28,33.33$ and 37.50 per cent by I-ELISA in Umreth, Anand, Khambhat, Tarapur, Anklav and Sojitra, respectively and none of samples were positive from Petlad and Borsad taluka of Anand district. In humans, occupation wise seroprevalence of brucellosis was $2(14.28 \%), 7(35.00 \%), 3(7.31 \%)$ and $3(6.00 \%)$ by IELISA among veterinary officers, para veterinarians, other staff related with animal husbandry activities and patient with unknown origin pyrexia respectively.
\end{abstract}

\section{Introduction}

Sheep and goat are an important species of livestock for India and play a vital role in the rural economy of India. They not only provide food security, employment and manure but also have great social value (Chopade et al., 2010).
Brucellosis is considered to be the most important disease due to its economic impact it has an adverse effect on total animal protein supplies and severe health hazard to human (Al-Talafhah et al., 2003). It is a contagious disease caused by bacteria of genus Brucella (Scholz et al., 2010; Seleem et al., 2010). In India, B. melitensis biotype 1 was isolated in 
the states of Karnataka, Andhra Pradesh, Maharashtra and Gujarat. B. melitensis biotypes 1 and 3 in Haryana (Hemashettar et al., 1987). Farmers, veterinary surgeons and employees of the meat packing business have an occupational risk for brucellosis (Lopes et al., 2010). There are about 500,000 new human cases of brucellosis caused by Brucella melitensis reported annually worldwide which is making it the common estzoonosis (Seleem et al., 2010). Brucellosis in sheep and goat is characterized by abortion, stillbirths, retention of placenta and reproductive failure. Free grazing and movement with frequent mixing of flocks of sheep and goats are the main mode of disease transmission resulting in high prevalence and wide distribution of brucellosis in these animals in India (Smith and Kadri, 2005). B. melitensis is the main etiological agent of brucellosis in small ruminants. It is also the main agent responsible for human brucellosis, called as Malta fever (Alvarez et al., 2011). B. melitensis is the major cause of abortion in goats and sheep in many countries including India. The infection is wide spread in India (Kapur and Grewal, 1974; Sreemannarayana, 1980; Ghosh and Verma, 1985).

\section{Materials and Methods}

The study was conducted to detect brucella antibodies for 325 sera samples comprising goat sera (100), sheep sera (100), veterinary officer (14), paraveterinarians (20), other staff related with animal husbandry activities (41) and human patient with unknown origin pyrexia (50) collected from various areas of Anand district, under aseptic precautions. These sera samples were tested for brucella antibodies using I-ELISA.

Brucella antibody test kit for I-ELISA was procured from Project Directorate on Animal Disease Monitoring and Surveillance (PD_ADMAS), Bangaluru and Brucella melitensis antibody test kit for I-ELISA was procured fromSpain INGEZIM Brucella Small Ruminantsi-ELISA. The samples were collected in vacutainer with serum clot activator and transported to the departmental P. G. research laboratory on icebox for further processing and serological analysis. The vacutainer was kept in upright position at room temperature for about $2 \mathrm{hr}$. Then the tubes were centrifuged at $3000 \mathrm{rpm}$ for 10 minutes to facilitate separation of serum, which was collected in a screw capped plastic vials. The sera were stored at $-20^{\circ} \mathrm{C}$ till subjected to I-ELISA.

\section{Results and Discussion}

The overall seroprevalence of brucellosis in animals (goats and sheep) was 93 (46.50\%) while species wise incidence was found to be $55(55.00 \%)$ and $38(38.00 \%)$ among goats and sheep, respectively. Out of $93(46.50 \%)$ seropositive samples $65 \quad(32.50 \%)$ were positive for Brucella melitensis comprising 46 goats and 19 sheep sera samples by I-ELISA (Fig. 1, 2 and 3; Table 1).

In case of sex wise seroprevalence of Brucella melitensis in male was 17.00 per cent while in case of female was 48.00 per cent by IELISA, respectively in small ruminants. In goats, sex wise seroprevalence of Brucella melitensis in male was 24.00 per cent while in female 68.00 per cent by I- ELISA. In sheep, sex wise seroprevalence of Brucella melitensis in male was 10.00 per cent while 28.00 per cent by I- ELISA in female (Fig. 4).

The findings of the present study seem to be in contrast with findings of Agasthya et al., (2012) who showed 3.6\% seroprevalence by I-ELISA in Karnataka. In addition, Verma (2013) who recorded 25 (13.5\%) samples were found to be seropositive for $B$. melitensis by dot-ELISA which was also lower then present finding. 


\section{Seroprevalence of brucellosis in humans}

In human beings overall seroprevalence was $12.00 \%$ by I-ELISA and none of sample positive by RBPT and STAT. In humans taluka wise seroprevalence of brucellosis was $12.50 \%, 33.33 \%, 16.66 \%, 14.28 \%, 33.33 \%$ and $37.50 \%$ by I-ELISA in Umreth, Anand, Khambhat, Tarapur, Anklav, Sojitra, respectively and none of samples positive in
Petlad and Borsad taluka of Anand district (Fig. 6 and table 2). In comparison to the present study similar seroprevalence was obtained by Tayshette (2001) who found $13.51 \%$ with dot-ELISA. In addition, Also Hussain et al., (2008) recorded seroprevalence of 11 percent by ELISA in Pakistan. Similarly, Magee (1980) who found $10.71 \%$ seroprevalence of brucellosis by IELISA.

Table.1 Seroprevalence of Brucella melitensis by I-ELISA

\begin{tabular}{|c|c|c|c|c|c|c|}
\hline \multirow[t]{3}{*}{ Species } & \multirow[t]{3}{*}{ Sex } & \multirow{3}{*}{$\begin{array}{l}\text { No. of } \\
\text { sera } \\
\text { samples } \\
\text { tested }\end{array}$} & \multicolumn{4}{|c|}{ Serological tests } \\
\hline & & & \multicolumn{2}{|c|}{$\begin{array}{c}\text { I-ELISA } \\
\text { (Brucella spp.) }\end{array}$} & \multicolumn{2}{|c|}{$\begin{array}{c}\text { I-ELISA } \\
\text { (B. melitsnsis) }\end{array}$} \\
\hline & & & $\begin{array}{l}\text { No. of samples } \\
\text { positive }\end{array}$ & $(\%)$ & $\begin{array}{l}\text { No. of samples } \\
\text { positive }\end{array}$ & $(\%)$ \\
\hline \multirow[t]{3}{*}{ Goat } & Male & 50 & 17 & $34 \%$ & 12 & $24 \%$ \\
\hline & Female & 50 & 38 & $76 \%$ & 34 & $68 \%$ \\
\hline & Total & 100 & 55 & $55 \%$ & 46 & $46 \%$ \\
\hline \multirow[t]{3}{*}{ Sheep } & Male & 50 & 11 & $22 \%$ & 5 & $10 \%$ \\
\hline & Female & 50 & 27 & $54 \%$ & 14 & $28 \%$ \\
\hline & Total & 100 & 38 & $38 \%$ & 19 & $19 \%$ \\
\hline \multirow[t]{3}{*}{ Total } & male & 100 & 28 & $28 \%$ & 17 & $17 \%$ \\
\hline & Female & 100 & 65 & $65 \%$ & 48 & $48 \%$ \\
\hline & Total & 200 & 93 & $46.50 \%$ & 65 & $32.50 \%$ \\
\hline
\end{tabular}

Table.2 Detection of Brucella IgG antibodies by I-ELISA in human beings

\begin{tabular}{|l|l|l|c|c|c|}
\hline Sr. No & $\begin{array}{l}\text { Name of } \\
\text { Taluka }\end{array}$ & $\begin{array}{c}\text { Sample collection } \\
\text { place }\end{array}$ & $\begin{array}{c}\text { Number of } \\
\text { samples tested }\end{array}$ & $\begin{array}{c}\text { Number of } \\
\text { Positive samples }\end{array}$ & Percentage \\
\hline 1. & Umreth & Umreth & 8 & 1 & $12.5 \%$ \\
\hline $\mathbf{2 .}$ & Anand & Chikhodara & 9 & 3 & $33.33 \%$ \\
\hline $\mathbf{3 .}$ & Khambhat & Khambhat & 12 & 2 & $16.66 \%$ \\
\hline $\mathbf{4 .}$ & Tarapur & Bhudhej & 7 & 1 & $14.28 \%$ \\
\hline $\mathbf{5 .}$ & Ankalav & Ankalav & 12 & 2 & $33.33 \%$ \\
\hline 6. & Petalad & Petalad & 8 & - & \\
\hline 7. & Sojitra & Dabhov & 13 & 3 & $37.50 \%$ \\
\hline 8. & Borsad & Borsad & 75 & - & 12 \\
\hline & & 50 & 3 & $6.00 \%$ \\
\hline $\begin{array}{l}\text { 9.Patient with unknown origin pyrexia } \\
\text { associated with animwal husbandry } \\
\text { activities }\end{array}$ & & & & \\
\hline Total & & 125 & 15 & $12.00 \%$ \\
\hline
\end{tabular}


Table.3 Occupations wise seroprevalence of brucellosis in humans

\begin{tabular}{|c|c|c|c|c|}
\hline Sr. No & $\begin{array}{l}\text { Occupational } \\
\text { categories }\end{array}$ & $\begin{array}{l}\text { Number of } \\
\text { samples } \\
\text { tested }\end{array}$ & $\begin{array}{l}\text { Number of } \\
\text { Positive } \\
\text { samples }\end{array}$ & Percentage \\
\hline 1. & $\begin{array}{l}\text { Veterinary } \\
\text { officers }\end{array}$ & 14 & 2 & $14.28 \%$ \\
\hline 2. & Para veterinarians & 20 & 7 & $35.00 \%$ \\
\hline 3. & $\begin{array}{l}\text { Other staff } \\
\text { related with } \\
\text { animal husbandry }\end{array}$ & 41 & 3 & $7.31 \%$ \\
\hline 4. & $\begin{array}{l}\text { Patient had } \\
\text { unknown origin } \\
\text { pyrexia }\end{array}$ & 50 & 3 & $6.00 \%$ \\
\hline \multicolumn{2}{|l|}{ Total } & 125 & 15 & $12.00 \%$ \\
\hline
\end{tabular}

Fig.1 Microtitre plate showing the results of I-ELISA for detection of Brucella antibodies. C+ (Positive control), C- (Negative control) and Rest of the well: Field serum samples

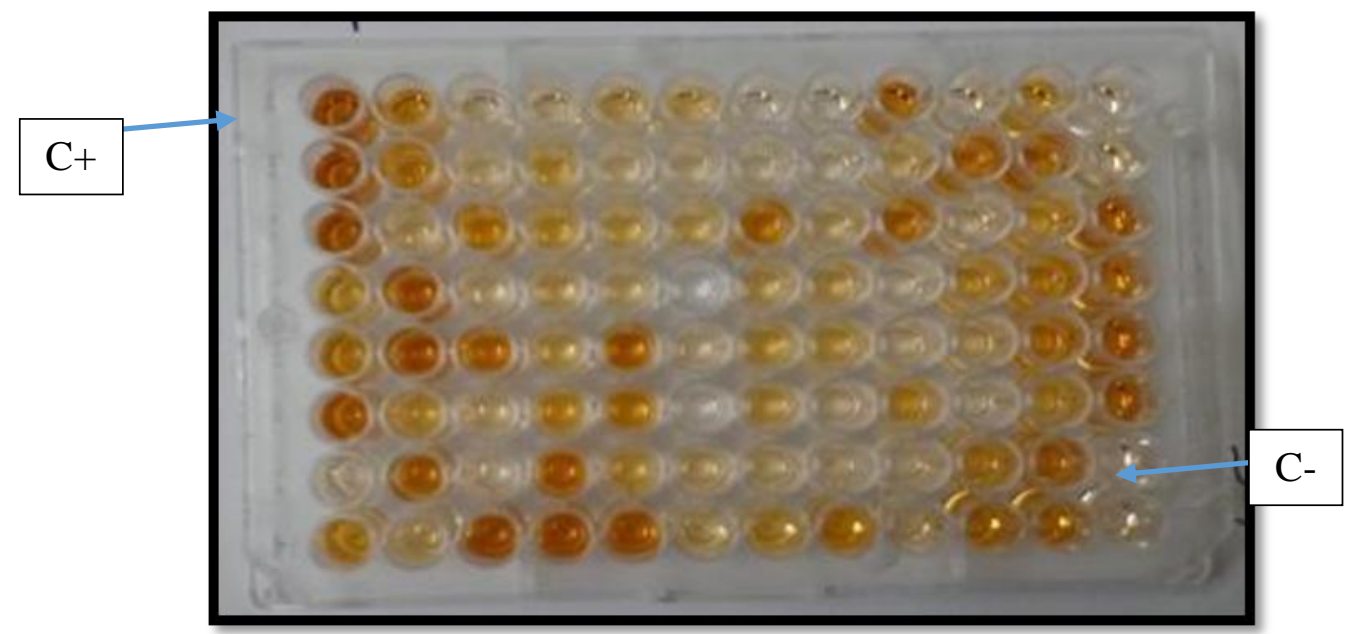

Percent positive $=(\mathrm{OD}$ value of test serum $/ \mathrm{OD}$ value of positive control $) \times 100$ More than $54 \%$ - Positive, below $54 \%$ - Negative and $54 \%$ - To be re-samples 
Fig.3 Species wise overall seroprevalence of Brucella melitensis in small ruminants

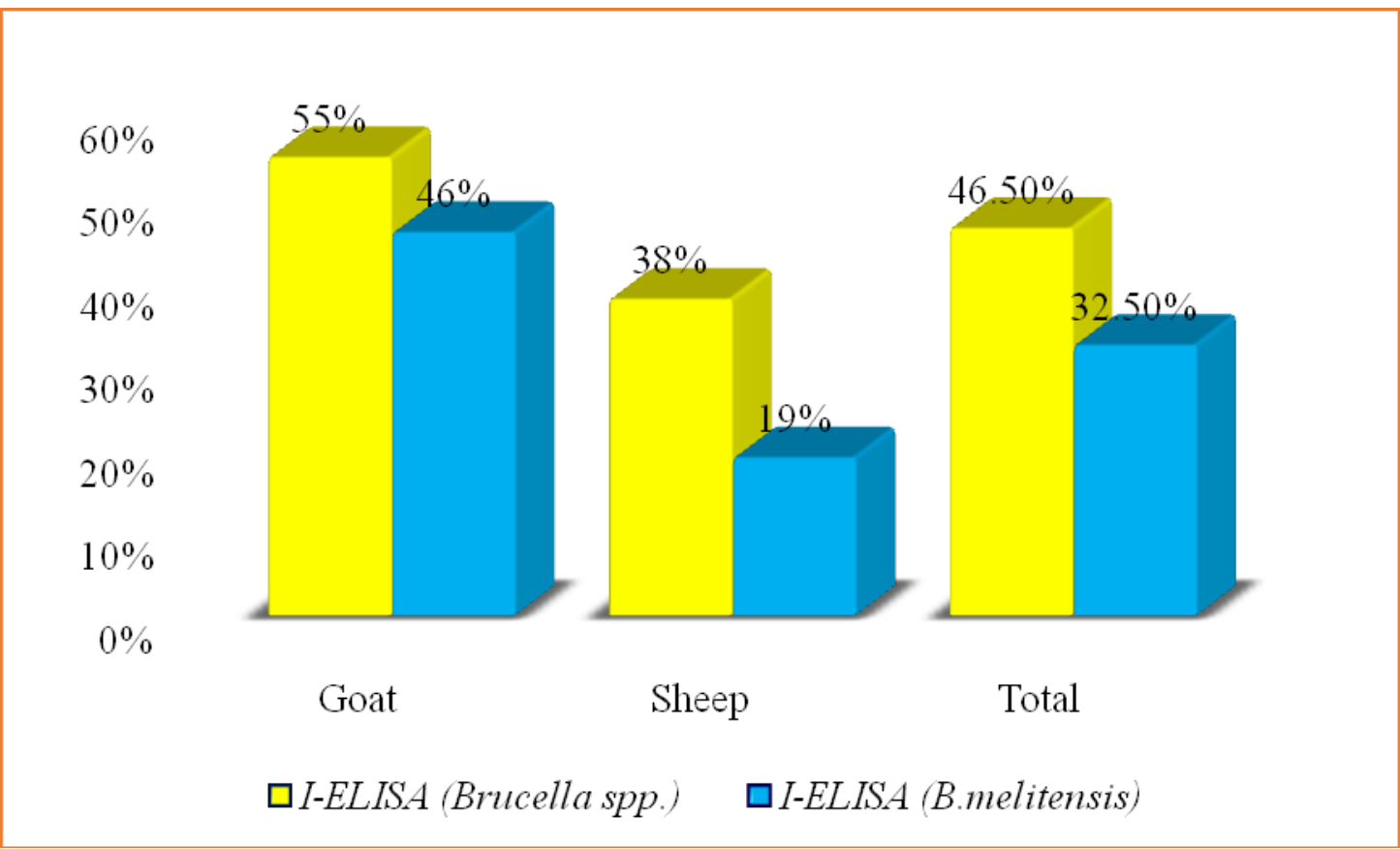

Fig.2 Microtitre plate showing the results of I-ELISA for detection of Brucella melitensis antibodies. $\mathrm{C}+$ (Positive control), $\mathrm{C}$ - (Negative control) and rest of the well: field serum samples

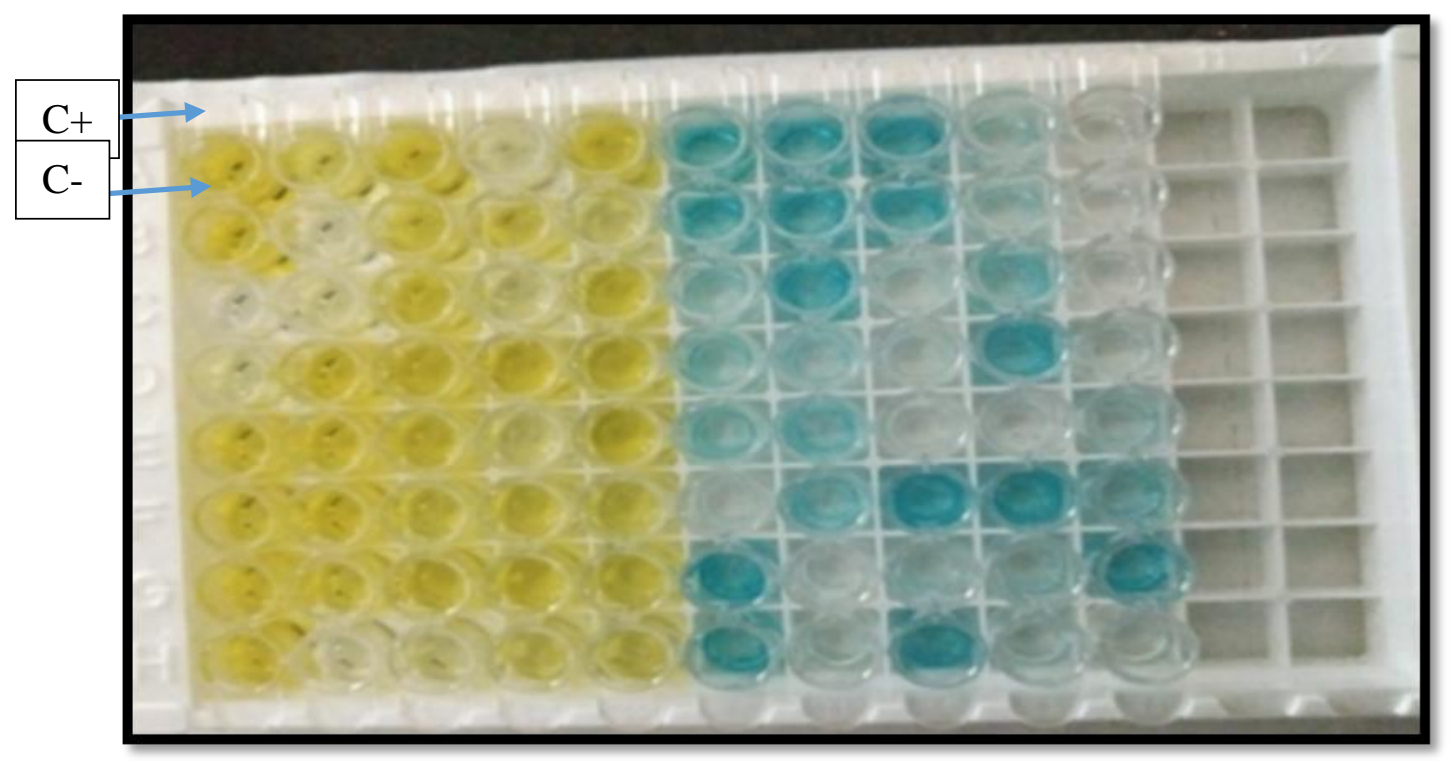

Positive Index (IP) $=$ OD 450 sample / OD $450 \mathrm{C}+$ ) X $100 \mathrm{IP}$ more than $25 \%$ must be considered as positive and lower than $25 \%$ considered as negative 
Fig.4 Sex wise seroprevalence of Brucella melitensis in small ruminants

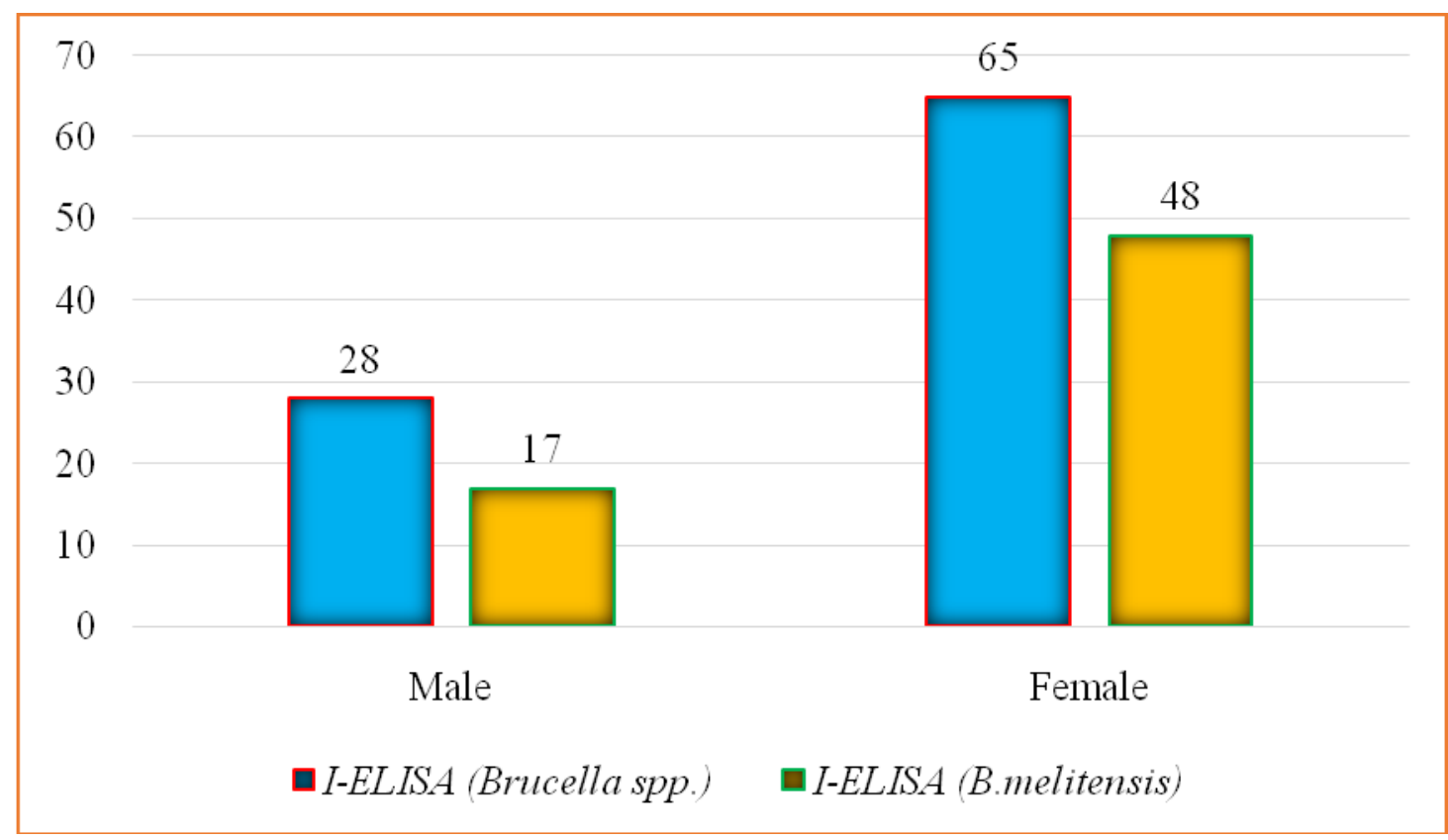

Fig.5 Microtitre plate showing the results of I-ELISA for detection of Brucella IgG antibodies from humans. $\mathrm{C}+$ (Positive control), $\mathrm{C}$ - (Negative control) and Rest of the well: Field serum samples

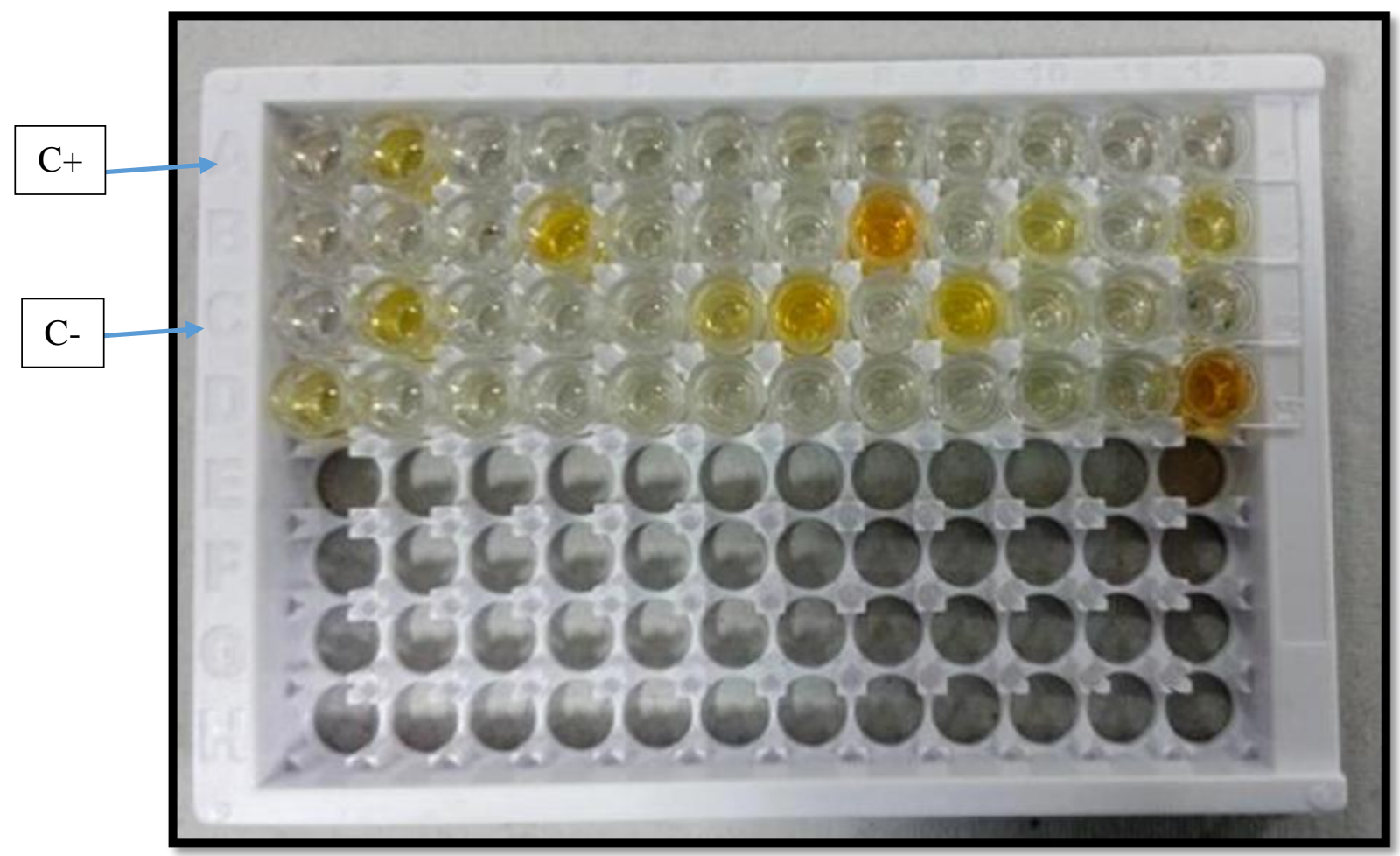

Positive negative value $(\mathrm{P} / \mathrm{N}$ value $)=$ OD 450 Sample $/$ Od 450 Negative $(\mathrm{P} / \mathrm{N}$ value more than $2.1-$ positive, $<1.5$ - negative and 1.5 to $<2.1-$ Suspectable 
Fig.6 Taluka wise seroprevalence of brucellosis in humans of Anand district

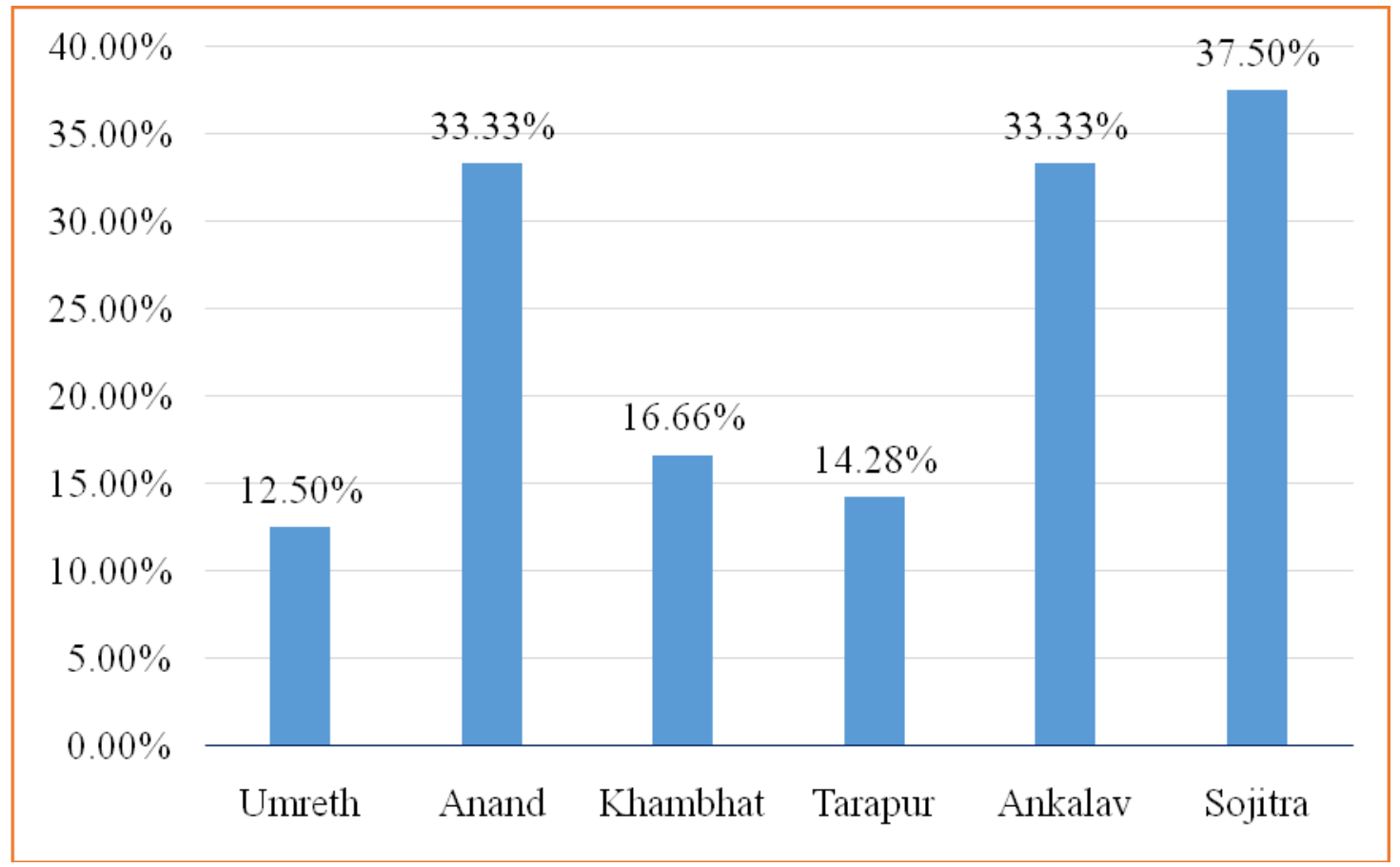

Fig.7 Occupations wise seroprevalence of brucellosis in humans of Anand district

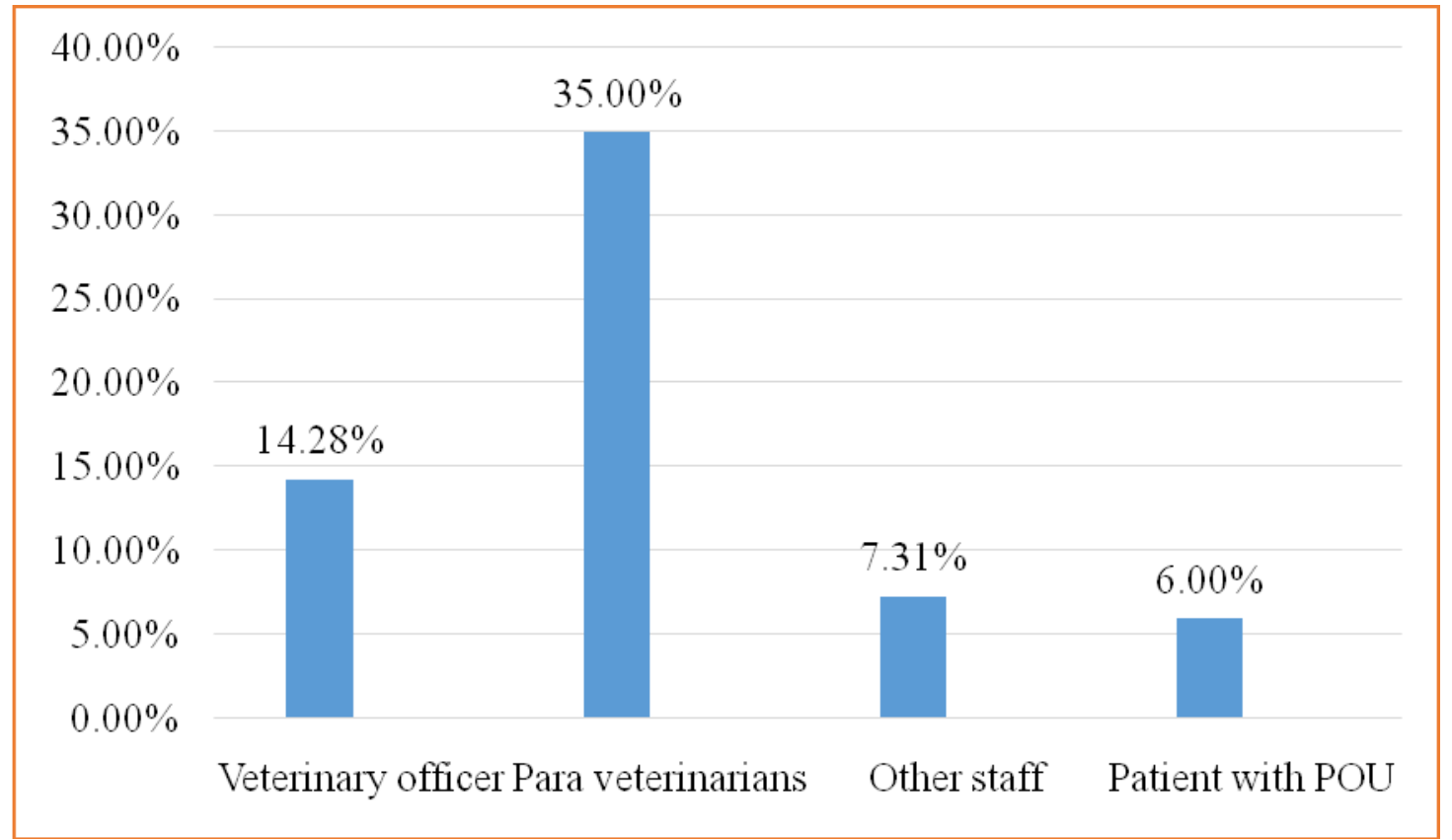

In contrast to be present study higher seroprevalence was obtained by Kalorey et al., (2000) who found $9.67 \%$ with RBPT as well as STAT. Similarly, Mohanty et al.,
(2000) who reported seroprevalence of brucellosis was $17(8.94 \%)$ and $13(6.84 \%)$ by RBPT and STAT. In addition, Kalla et al., (2001) $91.6 \%$ by RBPT in Rajasthan. In 
addition, Dimitrov et al., (2004) who observed $24.81 \%$ seropositivity by STAT. Similarly, Hussain et al., (2008) recorded seroprevalence was 14 per cent by RBPT in Pakistan. However, Otlu et al., (2007) who also observed 13, 14.22 and 17.88 per cent by RBPT, SAT and ELISA respectively. Similarly Mukhtar and Kokab (2008) found 21.7 per cent seroprevalence for anti Brucella IgG by ELISA.

\section{Occupations wise seroprevalence of brucellosis in humans}

In humans occupation wise seroprevalence of brucellosis was 2 (14.28\%), 7 (35.00\%), 3 $(7.31 \%)$ and $3(6.00 \%)$ by I-ELISA in veterinary officers, pera veterinarians, other staff related with animal husbandry and Patient had unknown origin pyrexia respectively (Table 3 and Figure 7).

Compared with present study lower seroprevalence was obtained by Shalmali et $a l .,(2012)$ who found $6.60 \%$ seroprevalence in Himachal Pradesh and in addition who also recorded prevalence in para veterinary staff $(8.33 \%)$, veterinarians $(7.14 \%)$, livestock owners $(5.71 \%)$. Similarly Pathak et al., (2014) who recorded $4.96 \%$ were seroprevalence from cases of pyrexia of unknown origin (PUO) and occupationally exposed individuals by IgG ELISA.

The variation in results of different tests could be because of the various factors such as occupation and stage of infection.

\section{Acknowledgement}

The authors are highly thankful to the Dean, College of Veterinary science and A.H. Anand for financial assistance and research facilities to conduct this research work and also thankful to Dr. Snehal Patel Deputy director of animal husbandry of Annand district for kind support.

\section{References}

Agasthya AS, Isloor S, Krishnamsetty $\mathrm{P}$. Seroprevalence study of human brucellosis by conventional tests and indigenous indirect enzyme-linked immunosorbent assay. The Scientific World Journal. 2012; 1-5.

Al-Talafhah AH, Lafi SQ, Al-Tarazi Y. Epidemiology of ovine brucellosis in Awassi sheep in Northern Jordan. Preventive veterinary medicine. 2003 Sep 12; 60(4):297-306.

Álvarez J, Sáez JL, García N, Serrat C, PérezSancho M, González S, Ortega MJ, Gou J, Carbajo L, Garrido F, Goyache J. Management of an outbreak of brucellosis due to $B$. melitensis in dairy cattle in Spain. Research in veterinary science. 2011 Apr 30; 90(2):208-11.

Chopade SR, Kalbande VH, Shelke SK, Dandage SD. Growth performance and economics of urea treated soybean straw based pelleted complete ration in kids. Indian Journal of Animal Nutrition. 2010; 27(2):138-41.

Dimitrov T, Panigrahi D, Emara M, Awni F, Passadilla R. Seroepidemiological and microbiological study of brucellosis in Kuwait. Medical Principles and Practice. 2004 Jun 10; 13(4):215-9.

Ghosh SS, Verma PC. Incidence of brucellosis in sheep and goat in Nagaland [India]. Short communication. Indian Veterinary Journal. 1985; 62: 339-340.

Hemashettar BM, Patil CS, Jayakumar K, Devaraj M, Nagalotimath SJ. isolation of Brucella melitensis biotype. 1. From a cow and 2 of its attenders. Indian Veterinary Journal. 1987 Oct 1; 64(10):822-5.

Kalla A, Chadda VS, Gupta A, Jain S, Gupta BK, Chaddha S, Nayak KC, Singh VB, Kumhar MR. Outbreak of polyarthritis with pyrexia in Western Rajasthan. The 
Journal of the Association of Physicians of India. 2001 Oct; 49: 963-5.

Kalorey DR, Single VC, Kurkure NV. Seroprevalence of brucellosis in livestock and humans in Vidarbha region. The Indian Journal of Animal Sciences. 2000 Feb 1; 70(2). 149-150.

Kapur MP and Grewal JS. Prevalence of brucellosis in domestic animals of Haryana state. Haryana veterinarian. 1974. 13: 1-4.

Lopes LB Nicolino R, PA Haddad J. Brucellosis-risk factors and prevalence: a review. The Open Veterinary Science Journal. 2010; 4(1): 72-84.

Magee JT. An enzyme-labelled immunosorbent assay for Brucella abortus antibodies. Journal of medical microbiology. 1980 Feb 1; 13(1):16772.

Mohanty TN, Panda SN, Das BR, Pradhan SK, Pradhan RK. Sero-incidence of brucellosis among dairy farm workers in Orissa. Indian Veterinary Journal. 2000; 77(7):568-70.

Mukhtar F, Kokab F. Brucella serology in abattoir workers. J Ayub Med Coll Abbottabad. 2008; 20(3):57-61.

Otlu S, Sahin M, Atabay HI, Unver A. Serological investigations of brucellosis in cattle, farmers and veterinarians in the kars district of Turkey. ActaVeterinaria Brno. 2008; 77(1):11721.

Hussain I, Arshad MI, Mahmood MS, Akhtar M. Seroprevalence of brucellosis in human, cattle, and buffalo populations in Pakistan. Turkish Journal of
Veterinary and Animal Sciences. 2008 Jul 16; 32(4):315-8.

Scholz HC, Nöckler K, Göllner C, Bahn P, Vergnaud G, Tomaso H, Al Dahouk S, Kämpfer P, Cloeckaert A, Maquart M, Zygmunt MS. Brucella inopinata sp. nov., isolated from a breast implant infection. International journal of systematic and evolutionary microbiology. 2010 Apr 1; 60(4):801-8.

Seleem MN, Boyle SM, Sriranganathan N. Brucellosis: a re-emerging zoonosis. Veterinary microbiology. 2010 Jan 27; 140(3):392-8.

Shalmali, Panda, A. Chahota, R. Seroprevalence of Brucellosis in Occupationally Exposed Human beings of Himachal Pradesh (India). J. Commun. Dis. 2012; 44(2), 91-95

Smits HL, Kadri SM. Brucellosis in India: a deceptive infectious disease. Indian Journal of Medical Research. 2005 Nov $1 ; 122(5): 375$.

Sreemannarayana O. Incidence of brucellosis in goats in Guntur (AP). Indian Veterinary Journal. 1980; 57(2):175176.

Tayshete SR. Seroprevalence of brucellosis in North Gujarat. MV Sc (Doctoral dissertation, Thesis Submitted to SDA University, SK Nagar, Gujarat).

Verma DK. Detection of anti-brucella antibodies in goats using $84 \mathrm{kda}$ soluble antigens of $\mathrm{b}$. Melitensis in dot-elisa. Int. J. Int sci. Inn. Tech. Sec. B. 2013 Oct; 2(5):22-6.

\section{How to cite this article:}

Padher, R.R., J.B. Nayak, M.N. Brahmbhatt, S.M. Patel and Chaudhary, J.H. 2018. Seroprevalence of Brucella melitensis among Small Ruminants and Humans in Anand Region of Central Gujarat. Int.J.Curr.Microbiol.App.Sci. 7(03): 3522-3530.

doi: https://doi.org/10.20546/ijcmas.2018.703.405 